\title{
A histological and histomorphometrical evaluation of screw-type calciumphosphate (Ca-P) coated implants; an in vivo experiment in maxillary cancellous bone of goats
}

\author{
J. E. G. HULSHOFF, K. VAN DIJK, J. P. C. M. VAN DER WAERDEN, W. KALK, \\ J. A. JANSEN \\ University of Nijmegen, Department of Oral Function, Laboratory of Biomaterials, Dental \\ School, PO Box 9101, 6500 HB Nijmegen, The Netherlands
}

The bone response to different calcium phosphate (Ca-P) coated implants was evaluated in a goat animal model. Two types of plasma spray coatings were applied to a commercially pure titanium (cpTi) tapered, conical screw-design implant (BioComp ${ }^{\circledR}$ ); hydroxyapatite (HA-PS) and a dual coating, consisting of FA and HA (FA/HA-PS). In addition an amorphous RF magnetron sputter coating (Ca-P-a) and uncoated implants were investigated. Forty-eight implants were inserted in the maxilla of 12 adult female goats. After implantation periods of 3 and 6 months, the bone implant interface was evaluated histologically and histomorphometrically. After both implantation periods all plasma spray coated implants were maintained. On the other hand three $\mathrm{Ca}-\mathrm{P}-\mathrm{a}$ and two $\mathrm{cpTi}$ implants were lost. Histological examination revealed a better bone response to both plasma spray coated implants. Histomorphometrical evaluation confirmed this finding. At 3 and 6 months significantly higher percentages of bone contact ( $p<0.001$, ANOVA) were measured for both plasma spray coated implants than for the cpTi and Ca-P-a implants, while no significant difference $(p<0.05)$ existed between both implantation periods. Degradation of both plasma spray coatings was observed. Supported by the results, it is concluded that, although $\mathrm{Ca}-\mathrm{P}$ coatings can improve the performance of dental implants, the presence of a $\mathrm{Ca}-\mathrm{P}$ coating is not the only important factor for bone healing around implants placed in low density trabecular bone.

\section{Introduction}

Considering the concern which has been raised about the viable use and long-term prognosis of plasmasprayed calcium phosphate $(\mathrm{Ca}-\mathrm{P})$ coated implants $[1,2]$, experimental efforts in our laboratory have been directed to the development of a RF magnetron sputter technique for the deposition of Ca-P coatings [3-6]. In earlier studies it was demonstrated that previous roughening of an implant, as for plasmaspraying, is not required to produce an adhesive coating [3]. In addition, physicochemical analysis confirmed the apatite nature of the applied films [3-6] Cell culture experiments demonstrated that the sputtered coatings were biocompatible and induced apatite formation [7]. Finally, in an in vivo rabbit experiment, where sputtered and plasma-spray coated implants were installed in the trabecular bone of the femoral condyles, no difference was found in bone healing response between these two types of $\mathrm{Ca}-\mathrm{P}$ coatings [8].

Despitc these favourable results it is known that the final bone response to an implant is also determined by the quality of the surrounding bone. For example, it is supposed that bone of low density, as found in the maxilla, can delay bone repair during the healing phase. To investigate this influence, a goat animal model was developed to install oral implants into the low density trabecular bone of the maxilla. Using this model, Caulier et al. observed significantly improved bone response to plasma-spray $\mathrm{Ca}-\mathrm{P}$ coated implants [9].

In view of the above, the aim of the present investigation was to study the biological behaviour of plasma spray and magnetron sputter $\mathrm{Ca}-\mathrm{P}$ coatings in the low density trabecular bone of the goat maxilla.

\section{Materials and methods}

\subsection{Implant materials and coating} characteristics

Forty-eight commercially pure titanium implants (cpTi) with a tapered, conical screw design (BioComp $^{\circledast}$ Industries, Medemblik, The Netherlands) werc used (Fig. 1). All implants measured $10.0 \mathrm{~mm}$ in length. Depending on the final coating procedure which was given to the implants, 24 of these implants 


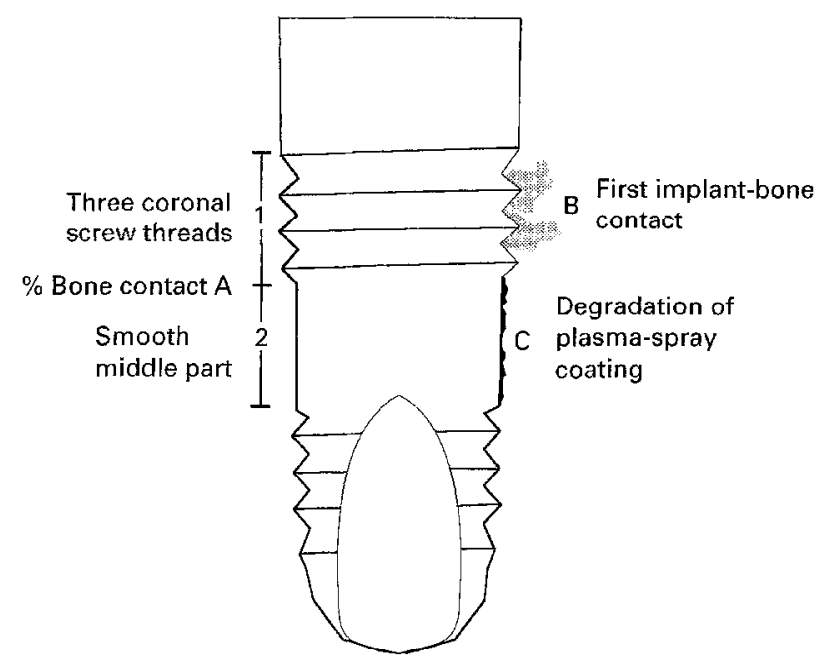

Figure I Schematic drawing of the tapered conical screw type implant. Areas of interest (A, B, C) for histomorphometrical evaluation are indicated.

had a diameter of $3.9 \mathrm{~mm}$, and the other 24 implants had a $4.0 \mathrm{~mm}$ diameter. This diameter was measured at the upper coronal neck of the implant. Using the plasma-spray and magnetron sputter technique the following coatings were deposited:

1. Twelve $3.9 \mathrm{~mm}$ implants were provided with a hydroxyapatite plasma spray coating (HA-PS) of approximately $50 \mu \mathrm{m}$ thickness, using spray-dried powder with a mean particle size of $32.5 \mu \mathrm{m}$ and consisting of $99 \%$ HA (CAM 2, CAM Implants B.V., Leiden, The Netherlands).

2. The other 12 implants with $3.9 \mathrm{~mm}$ diameter were provided with an experimental bilayered $\mathrm{Ca}-\mathrm{P}$ coating (CAM Implants B.V., Leiden, The Netherlands) of approximately $60 \mu \mathrm{m}$ thickness (FA/HA-PS). First the implants were coated with a $30 \mu \mathrm{m}$ thick fluorapatite layer. This layer was subsequently covered with a $30 \mu \mathrm{m}$ thick hydroxyapatite coating. The fluorapatite powder had a mean particle size of $36.9 \mu \mathrm{m}$ and a composition of $>99 \%$ FA. For the HA layer the same powder was used as for the HA-PS implants.

3. Twelve of the $4.0 \mathrm{~mm}$ implants were provided with a magnetron sputter coating ( $\mathrm{Ca}-\mathrm{P}-\mathrm{a})$ with a thickness of approximately $2.0 \mu \mathrm{m}$.

In addition twelve $4.0 \mathrm{~mm}$ implants (cpTi) were left uncoated.

To obtain adhesion of the plasma spray coatings, implants were grit blasted with $\mathrm{Al}_{2} \mathrm{O}_{3}$ to a surface roughness of $R_{\mathrm{a}}=4-5 \mu \mathrm{m}$.

Magnetron-sputter coating was performed as described earlier [3-6], using a commercially available unit (Edwards High Vacuum ESM 100 system). An HA plasma-sprayed copper disc served as a target for the sputter deposition. Before coating, the implants were mounted onto the rotating and water-cooled substrate holder. Coatings were applied on the asmachined surface of the implants.

The chemical composition of coatings was confirmed by X-ray diffraction (XRD), Fourier transform infrared spectroscopy (FTIR) and Rutherford backscattering spectrometry (RBS).

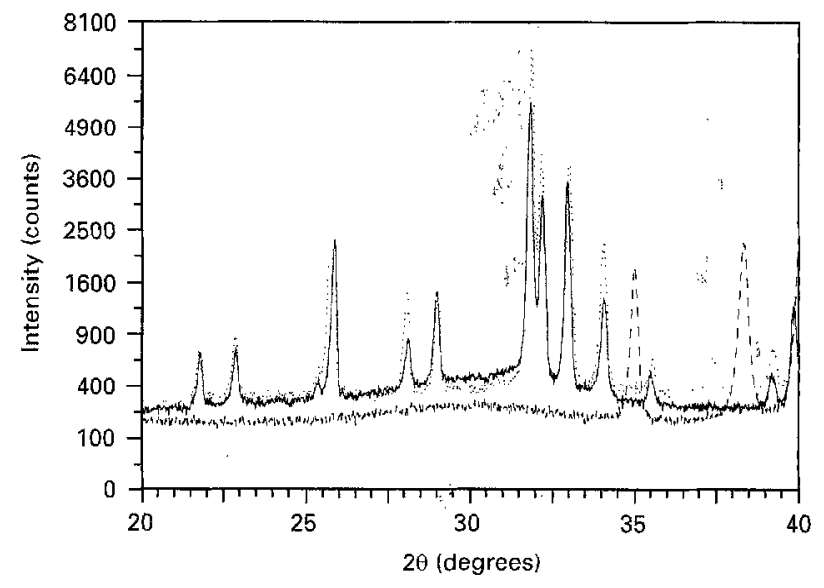

Figure 2 XR D patterns of the different Ca-P coatings:- HA-PS; - Ca-P-a; ... FA/HA-PS.

XRD (Fig. 2) of the plasma-sprayed FA part of the dual coating revealed $>98 \%$ crystallinity, and the HA part of this coating was $60 \%$ crystalline. For the plasma-sprayed HA coating, $64 \%$ crystallinity was measured. FTIR showed partial dehydroxylation for both HA-PS and the HA part of the FA/HA-PS coatings.

The XRD pattern (Fig. 2) of the Ca-P-a coating showed an amorphous structure without any specific reflection lines. Analysis of the FTIR spectra of the $\mathrm{Ca}-\mathrm{P}$-a coating showed a broad region which can be attributed to the internal vibrations of phosphate groups. This is indicative of the formation of amorphous calcium phosphate phases. Also a large $\mathrm{H}_{2} \mathrm{O}$ region was shown. RBS measurements of this coating revealed a $\mathrm{Ca} / \mathrm{P}$ ratio of 2.2 .

Before surgery, all implants were cleaned ultrasonically in $100 \%$ ethanol. Subsequently, they were sterilized in a steam autoclave.

\subsection{Experimental design and surgical procedure}

Twelve healthy, mature (2-4 years of age), female Saanen goats, weighing about $60 \mathrm{~kg}$ were used in this study. Prior to surgery, blood samples of the goats were taken to ensure that the animals were $\mathrm{CAE} / \mathrm{CL}$ arthritis-free. The animals were housed in a stable.

From each of the twelve goats, the first and second maxillary premolars were bilaterally extracted. The goats were immobilized on their backs and anaesthesia was induced by an intravenous injection of Thiopenta ${ }^{\oplus}$ and maintained by ethrane $2-3 \%$, administered through an orotracheal tube. The mouth of the goats and the skin around the mouth were disinfected with Betadine-iodine. After careful extraction, the wounds were closed using resorbable vicryl 2-0 sutures.

Four months after tooth removal, again under general anaesthesia, implants were inserted in the edentulous part of the maxillary premolar regions. A longitudinal incision was made on the palatal side of the alveolar ridge and a full thickness mucoperiosteal flap was prepared to both the buccal and palatal side of the alveolar ridge. After exposure of the 
alveolar ridge, two $1.6 \mathrm{~mm}$ pilot holes were drilled. The distance between the two holes was approximately $1 \mathrm{~cm}$. These holes were gradually widened with drills to the final diameter $(4 \mathrm{~mm})$ of the implants. The bone preparation was performed with a very gentle surgical technique using low rotational speeds (max. $450 \mathrm{rpm}$ ) and continuous internal and external cooling. After implant insertion, the wounds were closed using resorbable sutures (vicryl 2-0). To reduce the risk of peri-operative infection, a prophylactic antibiotic $\left(\right.$ Albipen ${ }^{\oplus}$ ) was administered for 3 days. Each goat received four implants; two in the left and two in the right maxillary alveolar ridge. The implants were inserted following a balanced split plot design. Three and 6 months after implantation a group of six animals was sacrificed using an overdose of Nembutal ${ }^{\oplus}$.

\subsection{Histological procedure}

After sacrificing the animals, the maxillae was excised en bloc. These were divided into two smaller tissue blocks, a left and a right part; each containing two implants. X-rays were taken of these blocks to determine maintenance or loss of the implants. Thereafter they were fixed in $4 \%$ buffered formalin solution. Following dehydration by an ethanol series, the tissue blocks were embedded in methylmetacrylate. After polymerization nondecalcified thin $(10 \mu \mathrm{m})$ sections were prepared in the buccopalatal direction parallel to the long axis of the implant, using a modified sawing microtome (FMTA, The Netherlands) $[10,11]$. The sections were stained with methylene blue and basic fuchsin for light microscopical evaluation.

\subsection{Histological and histomorphometrical evaluation}

A Zeiss light microscope was used for histological evaluation. In addition, image analysis techniques (TCL-image) were used for histomorphometrical evaluation.

The following quantitative parametcrs wcrc assesed:

\subsubsection{Percentage of bone contact at the interface}

Measurements were performed (1) along three coronal screw threads, and (2) at the smooth middle part of the Biocomp ${ }^{\oplus}$ implant (Fig. 1). The amount of bone contact was defined as the percentage of implant length over which there was direct bone-to-implant contact without intervening soft tissue layers.

All quantitative measurements were performed on three different sections per implant.

Measurements were also carried out for the buccal and palatinal sites. Results are based on the average of these three measurements.

\subsubsection{First implant-bone contact}

Measured as the distance from the top of the implant to the first bone contact. The greater this value (min- imum $0 \mathrm{~mm}$, maximum $10 \mathrm{~mm}$ ), the lower the first bone contact (Fig. 1).

As previously, the measurements were based on three sections per implant.

\subsubsection{Degradation of the plasma spray coatings}

Measurements were performed at the smooth middle part of the implant (Fig. 1). Images were projected with a total magnification of $125 \mathrm{x}$ on a colour monitor, using a colour camera attached to the light microscope. Subsequently, 14 scan lines were projected over the video picture, perpendicular to the implant surface, and the spacing between the coating boundaries was calculated. This procedure resulted in a distant count of 168 for each coating type.

\section{Results}

During the test period the experimental animals remained in good health; no complications were observed. X-rays of the tissue blocks at sacrifice, showed loss of three Ca-P-a coated and two cpTi implants. Two implants were lost in the 3-months group; one $\mathrm{Ca}-\mathrm{P}-\mathrm{a}$ and one cpTi implant. Three implants were lost in the 6-month group; two Ca-P-a and one cpTi implants (Table I). The remaining 43 implants healed without any clinical signs of inflammation. A chisquare test revealed no significant difference in loss or maintenance between the Ca-P coated and noncoated implants, either for the 3-munths or for the 6-months group.

\subsection{Light microscopical evaluation}

Fig. $3 \mathrm{a}$ and $3 \mathrm{~b}$ show that the trabecular bone density in the goat maxilla is very low. The implants were positioned between the buccal cortical bone plate and the maxillary sinus. Examination of the histological sections revealed that five implants were partially situated inside the maxillary sinus. This did not result in an adverse tissue reaction. The bone reaction to both types of plasma spray coated implants was relatively uniform (Fig. 4a and 4b). At the interfaces of these implants large areas showed intimate contact with mature bone, while other parts showed a newly formed layer of bone. In addition, at 3 months parts of the implant interface were covered with a layer of osteoid. At 6 months more newly formed bone was recognized.

TABLE I Loss and retention of different implant materials for different implantation periods

\begin{tabular}{|c|c|c|c|c|}
\hline \multirow[b]{2}{*}{ Material } & \multicolumn{2}{|l|}{3 months } & \multicolumn{2}{|l|}{6 months } \\
\hline & Retained & Lost & Retained & Lost \\
\hline FA/HA-PS & 6 & 0 & 6 & 0 \\
\hline HA-PS & 6 & 0 & 6 & 0 \\
\hline Ca-P-a & 5 & 1 & 4 & 2 \\
\hline cpTi & 5 & 1 & 5 & 1 \\
\hline Total & 22 & 2 & 21 & 3 \\
\hline
\end{tabular}



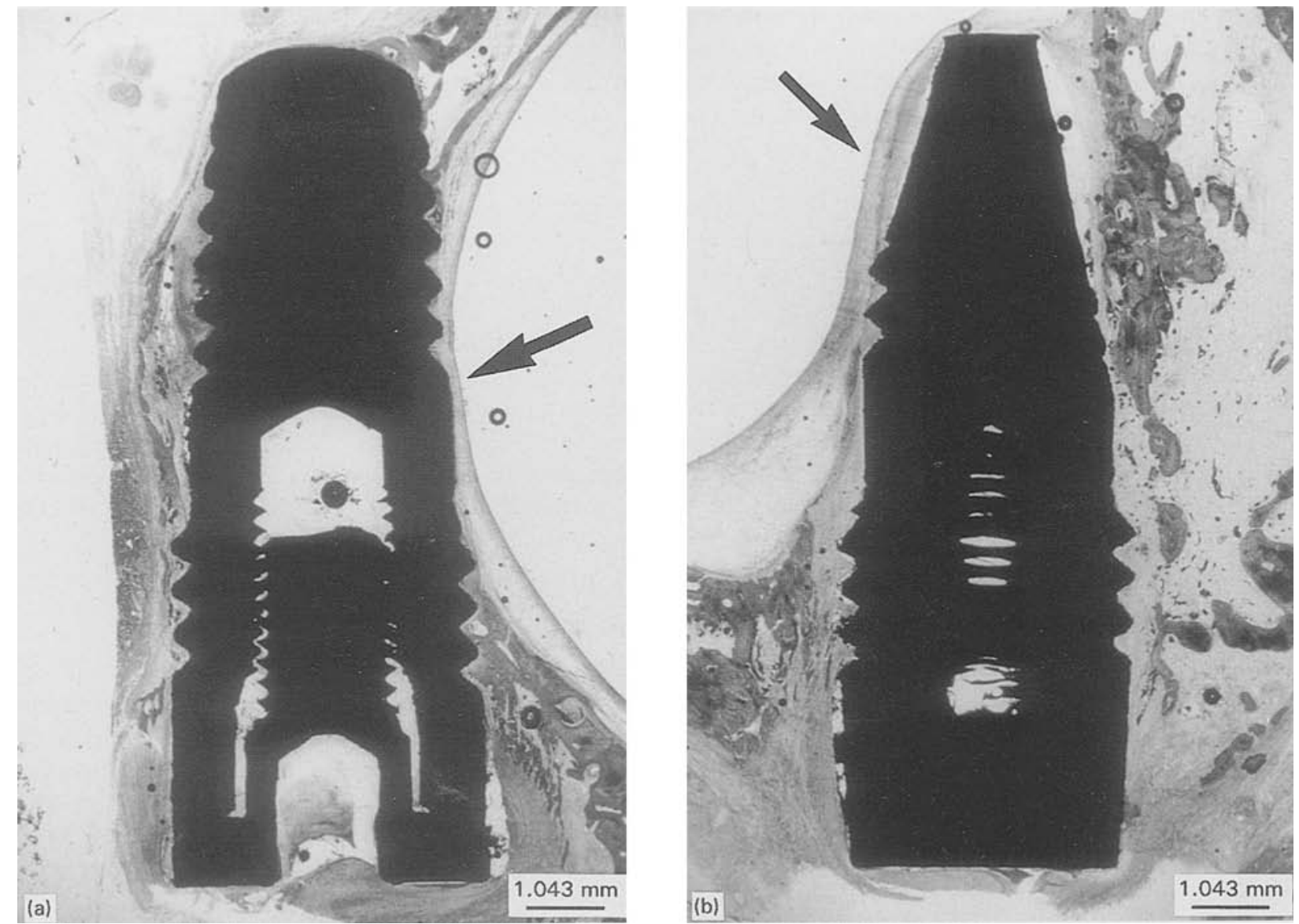

Figure 3 Light micrograph of (a) an HA-coated implant after 6 months of implantation, and (b) a Ca-P-a coated implant after 6 months of implantation. Low density of the trabecular bone of the goat maxilla can be noticed. Close proximity (a) to the maxillary sinus, and an implant position inside the sinus (b) is shown (arrows).
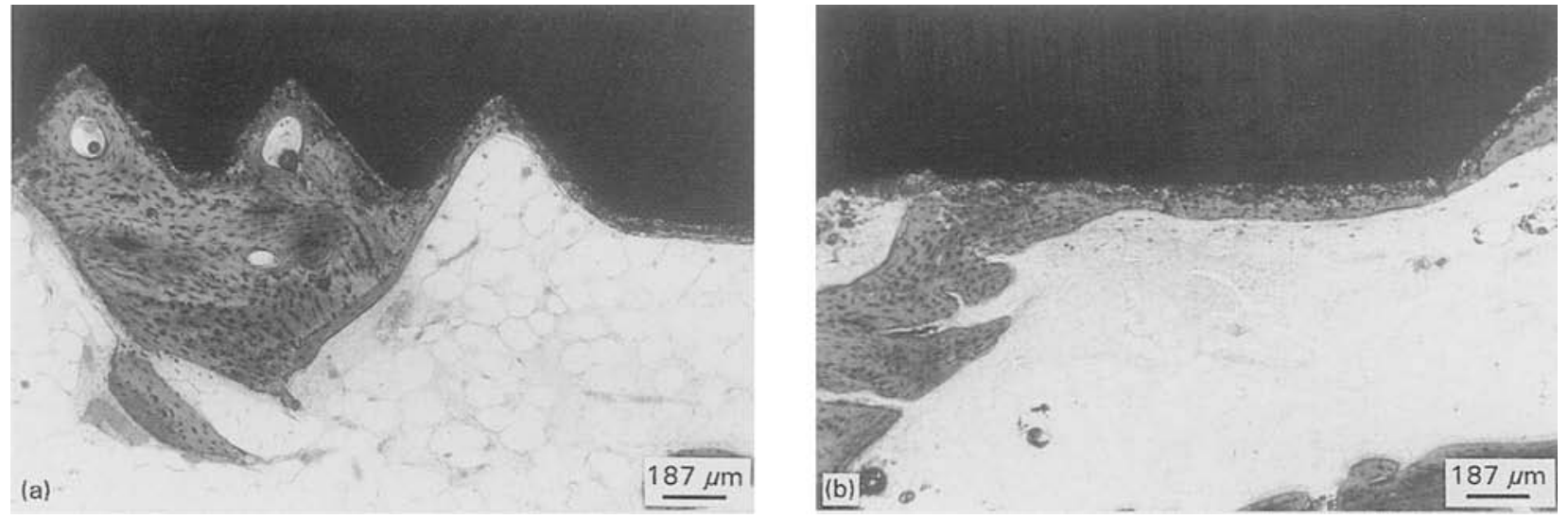

Figure 4 Light micrograph of (a) an HA-PS coated implant, and (b) a FA/HA-PS coated implant, both after 6 months of implantation. Good bone implant contact can be observed.

The cpTi and the Ca-P-a coated implants showed a very limited amount of bone contact. Most implants were almost completely surrounded by a fibrous tissue capsule (Fig. 5a and 5b). At 3 months bone was clearly separated from the implant. At 6 months bone grew closer to the implant interface. Also after 6 months of implantation some implants showed bone contact at the apex of the implant.

Both the HA-PS and FA/HA-PS coated implants revealed signs of degradation (Fig. $6 \mathrm{a}$ and $6 \mathrm{~b}$ ). This reduction was not uniform. For both, at some places the entire coating thickness was maintained, while at other sites no coating or only a thin layer was left. Absence of parts of these plasma spray coatings did not restrain direct bone contact: intimate bone contact could be recognized at these sites. A complete absence of plasma spray coating was more often seen for the HA-PS coating than for the FA/HA-PS coating. It appeared as if the HA-PS coating diffused inside its surrounding tissue, especially when it was not a mature type of bone. The surviving part of the FA/HAPS coating showed a more compact appearance. 

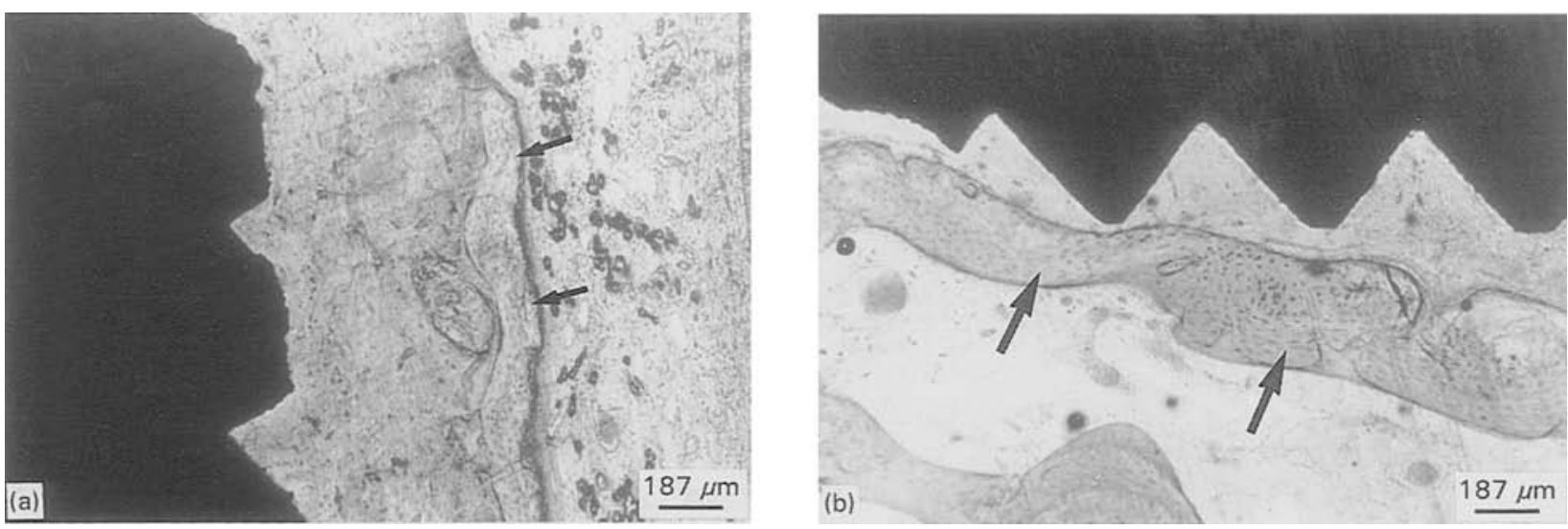

Figure 5 Histological appearance of (a) a Ca-P-a coated implant and (b) cpTi implant, both after 3 months. A fibrous layer of tissue interposes between bone (arrows) and implant.
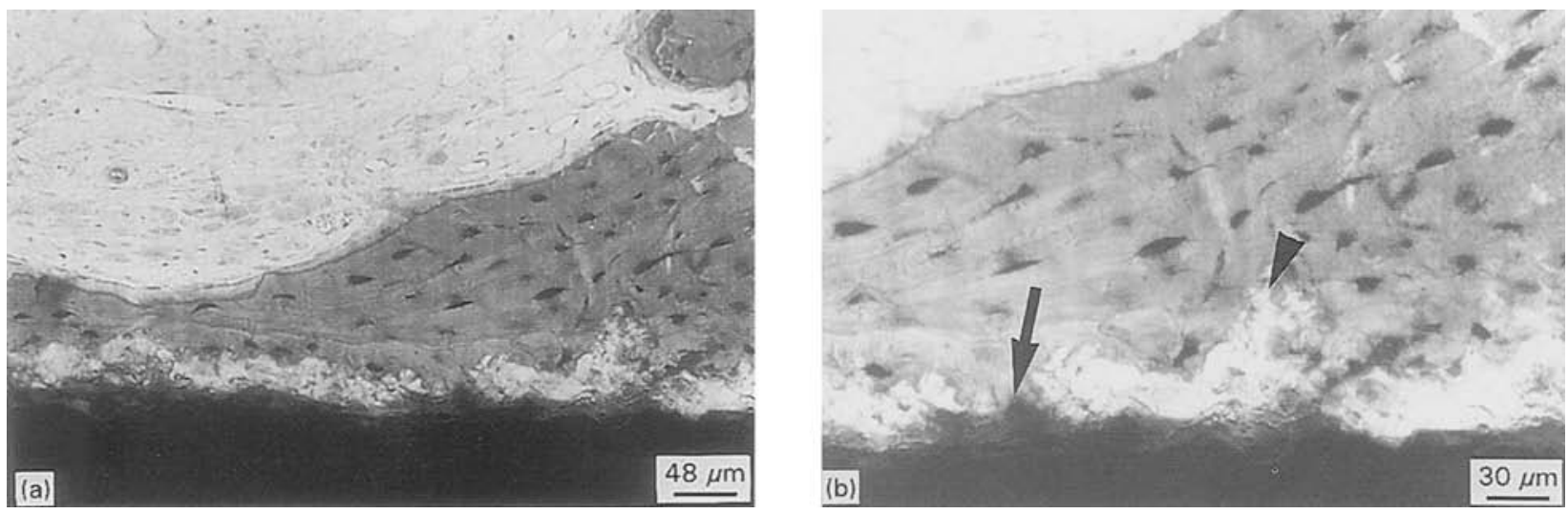

Figure 6 (a) FA/HA coated implant after 6 months of implantation. Degradation of the coating is not uniform. (b) Detail: both extremes are shown, complete absence of coating (arrow) or entire thickness (arrow head) maintained.

TABLE II Percentages of bone contact for various implants for both implantation periods

\begin{tabular}{|c|c|c|c|c|}
\hline & 3 months & & & \\
\hline & $\begin{array}{l}\text { Screw } \\
\text { threads }\end{array}$ & Std & Smooth part & Std \\
\hline FA/HA-PS & 53.9 & 13.4 & 67.2 & 26.5 \\
\hline HA-PS & 32.7 & 24.5 & 75.5 & 21.0 \\
\hline Ca-P-a & 0.0 & 0.0 & 0.0 & 0.0 \\
\hline сpTi & $\begin{array}{l}3.9 \\
6 \text { months }\end{array}$ & 8.8 & 4.0 & 8.9 \\
\hline $\mathrm{FA} / \mathrm{HA}-\mathrm{PS}$ & 59.8 & 22.5 & 41.9 & 16.1 \\
\hline HA-PS & 50.3 & 12.9 & 46.9 & 13.7 \\
\hline $\mathrm{Ca}-\mathrm{P}-\mathrm{a}$ & 4.0 & 5.2 & 5.1 & 3.5 \\
\hline cpTi & 4.2 & 5.1 & 5.1 & 8.1 \\
\hline
\end{tabular}

\subsection{Histomorphometrical evaluation}

In Table II results of the bone contact measurements are presented. As indicated by these results, minimal bone contact was measured for $\mathrm{cpTi}$ and $\mathrm{Ca}-\mathrm{P}-\mathrm{a}$ implants.

Statistical testing of the results using a one-way ANOVA and Tukey multiple comparison procedure revealed:

*A significant difference $(p<0.001)$ in bone contact between both types of plasma spray coated implants and the two other implant surfaces (Ca-P-a and cpTi).

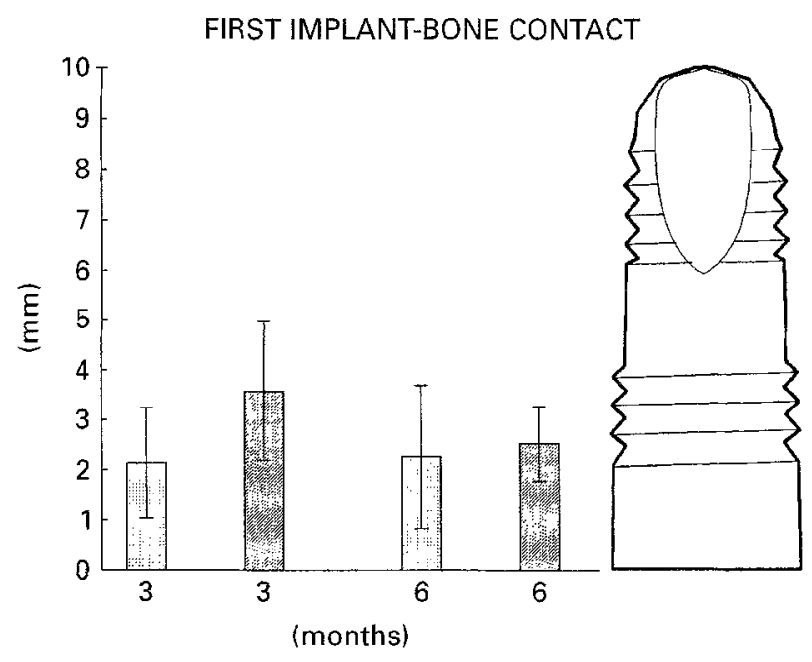

Figure 7 Bardiagram representing measurements of first implant-bone contact for the plasma-spray coated implants. The implant at the right of the diagram is in scale with the measurements: $\square$ FA/HA-PS; 國 HA-PS.

* No significant difference $(p<0.05)$ in bone contact existed between FA/HA-PS and HA-PS at both implantation periods.

*For all implant types no significant differences $(p<0.05)$ between 3 and 6 months of implantation.

Fig. 7 shows results of the first implant- bone contact measurements. Measurements for the Ca-P-a and cpTi were not involved in the bardiagram, since at 
TABLE III Degradation of plasma spray coatings. Mean values represent the thickness of the plasma spray coating at the smooth middle part of the implant

\begin{tabular}{llrll}
\hline & \multicolumn{2}{l}{3 months $(\mu \mathrm{m})$} & \multicolumn{2}{l}{6 months $(\mu \mathrm{m})$} \\
Material & Mean & Std & Mean & Std \\
\hline FA/HA-PS & 25.8 & 7.6 & 20.0 & 11.0 \\
HA-PS & 23.7 & 13.2 & 17.3 & 10.7 \\
\hline
\end{tabular}

both implantation periods all of these maintained implants were almost completely covered by fibrous tissue (Table II). Statistical testing revealed that no significant difference existed $(p<0.05)$ in the level of first implant-bone contact between both plasma spray coated implants for 3 and 6 months of implantation. In addition no significant difference $(p<0.05)$ was found between the implantation periods.

Results of the measurements of degradation of the plasma spray coatings are presented in Table III.

\section{Discussion}

The aim of the study was to investigate the behaviour of plasma-spray and RF magnetron-sputter Ca-P coatings in the low density trabecular bone of the goat maxilla.

The results revealed that plasma-spray coated implants showed more bone contact compared to noncoated and magnetron-sputter coated implants after 3 and 6 months of implantation. These findings confirm the results of other studies $[9,12-14]$ with plasma-spray Ca-P coated and non-coated implants. In addition, the data for non-coated as machined $\mathrm{T} i$ implants correspond with the earlier studies of Caulier et al. $[9,14]$. She also observed a very low percentage of bone contact to cylindrical screw shaped oral implants inserted in goat maxilla.

In contrast with previous in vitro and in vivo observations $[7,8]$, this present study failed to prove the beneficial effect of RF magnetron-sputter Ca-P coatings on the bone healing response. The inferior bone reaction, as found in the present study, could be due to the animal model used and the amorphous structure of the sputter coatings. The implants were inserted in a host bed of extremely low mineralization and density as compared to earlier experiments in the trabecular bone of rabbits. After insertion in bone tissue the bioactivity of $\mathrm{Ca}-\mathrm{P}$ ceramics is based on their ability to become coated with a layer of bone mineral (carbonate apatite) $[15,16]$. Normal remodelling of this at the surface of the ceramic deposited bone layer occurs. The Ca-P ceramic, when it is dense sintered, does not penetrate in the remodelling process nor is it resorbed by other processes. On the other hand, $\mathrm{Ca}-\mathrm{P}$ coatings on metallic substrates are subject to degradation, resulting in reduction of thickness [14,17-21]. For thin sputter-deposited coatings, the in vitro dissolution behaviour is determined by the degree of crystallinity of the coating [4]. It can be supposed that this dissolution process will be influenced by the wound healing response of the animal model. Species with a fast healing response (rats and rabbits) will show earlier formation of the carbonate apatite surface layer than animals with a slow healing response (goats and dogs). This hypothesis is supported by a recent study in which the surface features and dissolution properties of various amorphous and crystalline $\mathrm{Ca}-\mathrm{P}$ sputter coatings were determined after subcutaneous implantation in rabbits [22]. All amorphous coatings dissolved within 4 weeks of implantation. Crystalline coatings showed deposition of a granular precipitate consisting of $\mathrm{Ca}$ and $\mathrm{P}$ with a $\mathrm{Ca}-\mathrm{P}$ ratio of 1.0 to 1.75 . This precipitate grew in thickness until 4 weeks after implantation, while the coatings were still maintained. Consequently, it is supposed that complete dissolution of the amorphous coatings, as used in the current study, occurred, before it had the chance to influence the healing response. In addition, this explains why no significant difference in bone contact existed between the sputter coated and non-coated $\mathrm{Ti}$ implants.

Another remark has to be made about the difference in bone contact between both plasma-spray coated and the other implants. The plasma-spray coatings show a rough surface appearance. This may be an additional factor in the favourable bone response. This is confirmed by the results of other investigators $[23,24]$, who described stimulation of bone-implant contact by surface roughening compared to machineprcpared implants.

The present study showed no significant difference in bone reaction to the various implant surfaces between the 3 and 6 months installation periods. Therefore the question arises whether an intervening healing period of 6 months is necessary before loading an oral implant, even when they are installed in bone of low density. Although this type of bone, according to Lekholm and Zarb [25], can be defined as bone quality IV, it is not "diseased" bone with a lower healing capability. Evidently, bone healing after implant installation cannot be related to bone quality.

Considering the bone contact measurements, it should be noticed that the implant design could also have increased initial bone formation. Studies by Pilliar et al. $[26,27]$ showed that the design of the implant can significantly improve implant performance. Optimal results are obtained with a tapered conical implant shape similar to our implant. Support for the influence of the design factor is provided by a recent study by Caulier et al. [28]. In this experiment cylindrical HA plasma-spray coated implants were placed in goat maxillae also for 3 and 6 months periods. However, the average bone contact percentages to these implants were only $35 \%$.

Finally, the histological evaluation confirmed earlier reports about the degradation behaviour of plasma-sprayed Ca-P coatings. Both coatings showed a similar degradation pattern. After 6 months of implantation significant amounts of coating were left at the implant surface. Since some concern is raised about the fatigue strength properties of the remaining plasma-sprayed $\mathrm{Ca}-\mathrm{P}$ coatings in load bearing applications [1], the final consequences of this observation are not yet understood: long-term load studies have to be performed to provide this answer. 
According to the above, the clinical potential of FA/HA dual coatings is not clear. The supposed advantage of these coatings is based on improved bone healing response, as evoked by dissolution of the amorphous HA component followed by the biostable FA part of the coating. Nevertheless, in our study, no difference was observed in coating reduction or bone contact between HA-PS and FA/HA-PS coatings after 6 months of implantation.

On the basis of these findings it is concluded that the bioactive properties of amorphous Ca-P sputter coatings can be questioned. Apparently, determined by the bone conditions of the implant location, crystalline sputtered coatings are required to stimulate carbonate apatite deposition in vivo. Further, although extrapolation of animal studies to the human situation is always complicated, it is suggested that it is not necessary to wait for 6 months before loading a maxillary implant, when this implant is provided with an amorphous plasma-sprayed HA coating.

\section{Acknowledgements}

These investigations werc supported by the Netherlands Technology Foundation (STW).

The implants were kindly provided by Biocomp Industries, Medemblik, The Netherlands. The authors thank R.P.J. Wils for his surgical skills and assistance during the animal experiments and Mrs A.F.M. Leijdekkers-Govers for making histological sections.

\section{References}

1. I. M. O.KANGASNIEMI, C. C. P. M. VERHEIJFN, F. A. VAN DER VELDE and K. DE GROOT, J. Biomed. Mater. Res. 28 (1994) 563

2. J. E. DALTON and S. D. COOK, ibid. 29 (1995) 239.

3. J. A. JANSEN, J. G. C. WOLKE, S. SWANN, J. P. C. M. VAN DER W AERDEN and K. DE GROOT, Clin. Oral Impl. Res. 4 (1993) 28.

4. J. G. C. WOLKE, K. VAN DIJK, H. G. SCHAEKEN, K. DE GROOT and J. A. JANSEN, J. Biomed. Mater. Res. 28 (1994) 1477.

5. K. VAN DIJK, II. G. SCIIACKEN, J. G. C. WOLKE, C. H. M. MAREE, F. H. P. M. HABRAKEN, J. VERHOEVEN and J. A. JANSEN, ibid. 29 (1995) 269.

6. K. VAN DIJK, H. G. SCHAEKEN, J. C. G. WOLKE and J. A. JANSEN, Biomaterials 17 (1996) 405.

7. J. E. G. HULSHOFF, K. VAN DIJK, J. P. C. M. VAN DER WAERDEN, J. G. C. WOLKE, L. A. GINSEL and J. A JANSEN, J. Biomed. Mater. Res. 29 (1995) 967.
8. J.E. G. HULSHOFF, K. VAN DIJK. J. P. C. M. VAN DER WAERDEN, J. C. G. WOLKE, W. KALK and J. A. JAN. SEN, ibid. 31 (1996) 329.

9. H. CAULIER, J. P. C. M VAN DER WAERDEN. Y. C. G. J. PAQUAY, J. G. C. WOLKE, W. KALK, I. NAERT and J. A. JANSEN, JBMR. in press (1996).

10. H. B. M. VAN DER LUBBE, C. P. A. T. KLEIN and K. DE GROOT, Stain Technol. 63 (1988) 171.

11. C. P. A. T. KLEIN, Y. M. H. F. SAUREN, W. E. MODDERMAN and J. P. C. M. VAN DER WAERDEN, J. Appl. Biomater. 5 (1994) 369.

12. J. A. JANSEN, J. P. C. M. VAN DER WAERDEN, J. G. C. WOLKE and K. DE GROOT, J. Biomed. Mater. Res. 25 (1991) 973.

13. W. J. A. DHERT, C. P. A. T. KLEIN, J. A. JANSEN, E. A. VAN DER VELDE. R. C. VRIESDE, P. M. ROZING and K. DE GROOT, ibid. 27 (1993) 127.

14. H. CAULiER, J. P. C. M. VAN DER WAERDEN, Y. C. G. J. PAQUAY, J.G.C. WULKE, W. KALK, I. NAEKI and J. A. JANSEN, ibid. 29 (1995) 1061.

15. M. JARCHO, J. F. KAY, K. I. GUMAFR, R. H. DOREMUS and H. P. DROBECK, J. Bioengng. 1 (1977) 79.

16. M. JARCHO, Clin. Orhop. Rel Res. 157 (1981) 259.

17. J. A. JANSEN, J. P. C. M. VAN DER WAERDEN and J. G. C. WOLKE, J. Biomed. Mater. Res. 27 (1993) 603.

18. Idem., J. Mater. Sci. Mater. Med. 4 (1993) 466.

19. C. P. A. T. KLEIN, P. PATKA, H. B. M. VAN DER LUBBE, J. C. G. WOLKE and K. DE GROOT, J. Biomed. Mater. Res. 25 (1991) 53.

20. C. P. A. T. KLEIN, J. G. C. WOLKE, J. M. A. DE BLIECK HOGER VORST and K. DE GROOT, ibid. 28 (1994) 146.

21. W. J. A. DHERT, C. P. A. T. KLEIN, J. G. C. WOLKE. E. A. VAN DER VELDE, K. DE GROOT and P. M. ROZING, ibid. 25 (1991) 1183.

22. J. G. C. WOLKE, K. DE GROOT and J. A. JANSEN, in Annuals of the 5th World Biomaterials Congress, Toronto (1996) 630

23. A. WENNERBERG, T. ALBREKTSSON and B. ANDERSSON, J. Mater. Sci. Mater. Med. 6 (1995) 302

24. D. BUSER, R. K. SCHENK, S. STEINEMAN, J. P FIORELLINI, C. H. FOX and H. STICH, J. Biomed. Mater. Res. 25 (1991) 889.

25. U. LEKHOLM and G, A. ZARB, in "Tissue integrated prosthesis: osseointegration in clinical dentistry" edited by P. I Brånemark, G. Zarb, T. Albrektsson, (Quintessence, Chicago, 1985).

26. R. M. PILLIAR, D. A. DEPORTER, P. A. WATSON and N. VALIQUETTE, J. Biomed. Mater. Res. 25 (1991) 467.

27. R. M. PILLIAR, D. A. DEPORTER, P. A. WATSON, M. PHAROAH, M. CHIPMAN, N. VALIQUETTE, S. CARTER and K. DE GROOT, J. Dent. Res. 25 (1991) 1338.

28. H. CAULIER, S. VERCAIGNE, I. NAERT, J. P. C. M. VAN DER WAERDEN, J. C. G. WOLKE and J. A. JANSEN, J. Biomed. Mater. Res. (1996) in press.

Received 18 December 1995

and accepted 15 March 1996 